\title{
EXAMINATION OF THE BEHAVIOUR OF ESCHERICHIA COLI IN BIOFILMS ESTABLISHED IN LABORATORY- SCALE UNITS RECEIVING CHLORINATED AND CHLORAMINATED WATER
}

\author{
MAGGY N. B. MOMBA, T. E. CLOETE, S. N. VENTER and R. KFIR
}

\section{INTRODUCTION}

The formation and presence of biofllms in drinking water distribution systems have been reported frequently (LeChevallier et al, 1987; van der Wende and Characklis, 1990; White et al, 1996). Biofllms developing in drinking water distribution system can lead to pronounced changes in microbial quality resulting in customer dissatisfaction with taste and odour, industrial user complaints on product deterioration and hospital concerns for patient exposure (Wierenga, 1985; Geldreich and Rice, 1987). A large variety of different heterotrophic bacteria (including potentially pathogenic bacteria) have been isolated from the biofilm in distribution systems receiving both chlorinated and non-disinfected water (LeChevallier et al, 1987). The most alarming results are the presence and multiplication of pathogenic and opportunistic pathogens such as Escherichia coli, Pseudomonas, Aeromonas, Klebsiella, Legionella spp and Mycobacter occurring within biofllms (Engel et al, 1980; Wadowsky et al, 1982; Burke et al, 1984). The increase in reported cases of coliform occurrence in chlorinated drinking water has been related to outbreaks of waterborne diseases in the U.S. (Lippy and Waltrip, 1984).

$E$. coli has the important feature of being highly specific for the faeces of humans and warm-blooded animals. Generally E. coli fails to multiply in any natural water environment, and is, therefore, used as specific indicators for faecal pollution (Grabow, 1996; WHO, 1996). E. coli has been shown to be highly resistant to treatment process (Craun, 1991; Craun et al, 1994a). This form of resistance is often linked to the fact that a number of chemical and physical factors common to drinking water distribution systems are known to cause a form of sublethal and reversible injury during disinfection. These factors include chlorine and other biocides, low concentration of metals such as copper and zinc, extremes of temperature and $\mathrm{pH}$ and interactions with other bacteria (LeChevallier and McFeters, 1985). Several investigators have shown that coliforms could survive standard chlorine residuals with subsequent release into the distribution systems (McFeters et al, 1986). Attachment of bacteria to surfaces and specific growth conditions of bacterial cultures have also been shown to increase the chlorine resistance of bacteria. Ridgway and Olson (1982) showed high correlations between numbers of viable bacteria in chlorinated water and numbers of bacteria attached to particles. Research initiated by LeChevallier et al. (1987) indicated that coliforms in distribution systems originated from pipeline biofilms. Results showed that coliforms levels increased as the water moved from the treatment plant through the distribution systems. Computer modelling of hydraulic residence times showed that the increased coliform densities could not be accounted for by growth of the cells in the water column alone but must have come from biofilms in the distribution system. Results also showed that maintenance of $1-2 \mathrm{mg} 1^{-1}$ free chlorine residual was insufficient to eliminate these occurrences of coliforms. However, a recent study performed by Momba et al. (1998) reported the effectiveness of monochloramine in controlling biofilm regrowth in laboratory-scale unit when comparing to chlorine, ozone and UV. This suggested that monochloramine could play an important role in the reduction or elimination of coliform bacteria within biofilms. These findings led to investigate the behaviour of coliform bacteria within biofilms.

Moreover, most studies on the survival of coliform bacteria in drinking water distribution systems have been done using surface water. No information is available to date on the situation pertaining to coliform bacteria in biofilm formed in groundwater distribution systems. However ground-water remains the main water supply source for many small communities in semi arid areas such as part of South Africa. In the past the general perception was that groundwater has self purification properties and has long been considered to be of excellent quality. Nevertheless, groundwater from shallow wells are frequently grossly polluted. Reports of some waterborne outbreaks and unsatisfactory coliform results in groundwater have led to the recommendation to disinfect many well waters and springs used for drinking water (Lippy and Waltrip, 1984; Craun, 1985). In recent years due to the realisation that groundwaters are the cause of waterborne disease outbreaks, many South Africa rural communities have adapted some measure of disinfection (chlorine) which often coincide with small scale water distribution or storage systems. Consequently, the study on the behavior of coliform in groundwater proved to be important.

In this study, groundwater was used to examine the incorporation and survival of $E$. coli developing biofilms in laboratory-scale units, chlorine and monochloramine were used as disinfectants. 


\section{MATERIAL AND METHODS}

\section{Biofilm apparatus}

Three laboratory-scale units were used, one for each of the treatments and a separate unit for the control experiment (non-disinfected water). The unit consisted of 3 x 50 liter polyethylene drums which was used as a batch reactor. The batch reactor was attached to a peristaltic pump, which in turn was connected in series to a Pedersen device and a flow-through glass tube (Fig. 1). The purpose of a flowthrough glass tube was for biofilm monitoring.

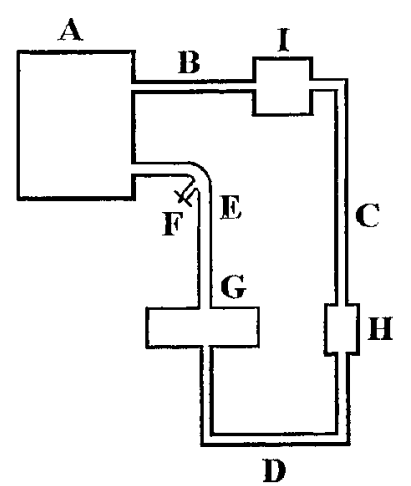

Fig. 1. Schematic diagram of the laboratory-scale unit: (A) a sterile drum; (B), (C), (D), (E) latex tubing to allow water circulation; (F) a tap to allow sampling; (G) Pedersen device; (H) flow-through glass tube and (I) a peristaltic pump.

The modified Pedersen device was used to allow biofilm formation to be studied. For this purpose, 20 stainless steel (316) coupons, the size of the microscope slide $(75 \times 25 \times 1 \mathrm{~mm})$, were installed vertically into the Pedersen device and used for the enumeration of attached viable bacteria and E. coli.

\section{Test organisms}

E. coli ATCC 11775 was used in the experiment. The culture was stored on nutrient agar (Merck) at $4^{\circ} \mathrm{C}$. When needed, 2 loops of $\mathrm{E}$. coli were transferred into $100 \mathrm{ml}$ nutrient broth (Merck) and aerobically cultured at $37^{\circ} \mathrm{C}$ for $24 \mathrm{~h}$.

\section{Source water and disinfection}

Chlorine and monochloramine were used to disinfect groundwater collected from a well in a rural area. Concentrated solutions of the disinfectants were added to the water to provide a final free chlorine concentration of $2 \mathrm{mg}^{-1}$ and a $1.5 \mathrm{mg}^{-1}$ monochloramine concentration. The concentrations of free chlorine and monochloramine residuals were measured using the $N, N$-diethyl-p-phenylenediamine (DPD, Sigma) ferrous titrimetric method (APHA, 1989). No neutralization was done during the experimental period for any of the disinfectants used.

\section{Biofilm formation}

The non-disinfected water (control water) and the 2 disinfected waters were transferred into experimental distribution systems designed for the study of biofilm production. Water circulation was facilitated at a flow rate of $2.81 \mathrm{~h}^{-1}$ and the experiments were conducted at room temperature. $24 \mathrm{~h}$ after circulation of raw water and disinfected water in different systems, E. coli was added to each systems to an initial concentration of $\pm 2.6 \times 10^{4}$ bacteria per liter. The experimental data is based on four replications of the study.

\section{Sampling and microbial analyses}

Stainless steel coupons were withdrawn $24 \mathrm{~h}$ (corresponding to $48 \mathrm{~h}$ in Table 1) after inoculation of $E$. coli and thereafter every day until the disinfectant concentrations had been completely eliminated in distribution systems (96 h). Attached bacteria were released from the stainless steel coupons by 2 min sonication (Bandelin Sonorex RK 255S) in $20 \mathrm{ml}$ sterile MilliQ water. Attached heterotrophic bacteria were enumerated by the standard spread plate procedure using R2A agar (Difco), incubated at $28^{\circ} \mathrm{C}$ for 7 days (Reasoner and Geldreich, 1985). 


\begin{tabular}{|c|c|c|c|}
\hline \multirow[t]{2}{*}{ Time } & \multicolumn{2}{|c|}{ Residual disinfectants } & \\
\hline & chlorine (mg / 1) & monochloramine (mg / 1) & \\
\hline 0 & 2 & 1.5 & \\
\hline $24 \mathrm{~h}$ & 0.7 & 0.8 & \\
\hline $48 \mathrm{~h}$ & 0.0 & 0.3 & \\
\hline \multirow[t]{2}{*}{$72 \mathrm{~h}$} & 0.0 & 0.0 & \\
\hline & non-disinfected water & chlorinated water & chloraminated water \\
\hline \multicolumn{4}{|c|}{ Attached heterotropic plate count bacteria (average cfu cm²) } \\
\hline $48 \mathrm{~h}$ & $9.33 \times 10^{4}$ & $8.36 \times 10^{3}$ & $1.78 \times 10^{2}$ \\
\hline $72 \mathrm{~h}$ & $4.30 \times 10^{4}$ & $5.69 \times 10^{3}$ & $8.89 \times 10^{2}$ \\
\hline $96 \mathrm{~h}$ & $1.80 \times 10^{4}$ & $1.78 \times 10^{3}$ & $4.00 \times 10^{2}$ \\
\hline \multicolumn{4}{|c|}{ 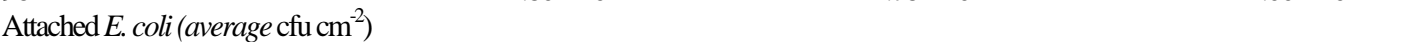 } \\
\hline $48 \mathrm{~h}$ & 9 & 2 & 0 \\
\hline $72 \mathrm{~h}$ & $3.32 \times 10^{2}$ & $1.8 \times 10^{2}$ & 0 \\
\hline $96 \mathrm{~h}$ & $1.88 \times 10^{2}$ & 2 & 0 \\
\hline
\end{tabular}

Analyses were carried out in duplicate. E. coli were enumerated by the membrane filter procedure using a filter with a $0.45 \mathrm{~nm}$ pore size (APHA, 1989). Membranes (Whatman) were placed on m-FC agar (Merck) and incubated for $24 \pm 2 \mathrm{~h}$ at $44.5 \pm 0.2^{\circ} \mathrm{C}$. Each determination was performed in triplicate.

\section{Statistical analyses}

To compare variation in treatments, ANOVA was applied to the bacterial counts with the latter as the dependent variable. The counts were transformed by taking logarithms base 10 (Lcount) to establish the variance. Times in hours from outset of the experimentation $(24 \mathrm{~h}$ after the addition of initial $E$. coli density) were included as a co-variate. If significant factors (e.g. treatments) were found, then the least significant difference test (LSD) was applied to establish which particular levels of a factor are different, in terms of the bacterial counts.

\section{RESULTS AND DISCUSSION}

Although the systems had different initial concentrations of free chlorine (2 $\mathrm{mg} 1^{-1}$ ) and monochloramine $\left(1.5 \mathrm{mg} 1^{-1}\right)$, the treated waters contained approximately the same concentration of disinfectant residual $\left(0.7 \mathrm{mg} 1^{-1}\right.$ for free chlorine and $0.8 \mathrm{mg}^{-1}$ for monochloramine) after $24 \mathrm{~h}$. Over a period of $24 \mathrm{~h}$, residual levels decreased in the systems, and no residual was present in the chlorinated water after $48 \mathrm{~h}$ (Table 1). Monochloramine residual could be detected up to $48 \mathrm{~h}\left(0.3 \mathrm{mg} 1^{-1}\right)$ and was only depleted within $72 \mathrm{~h}$. The persistence of monochloramine residual in potable water distribution systems was also found by others researchers (Mathieu et al., 1992), as well as during our study with bacterial regrowth or biofilm formation in potable surface water (Momba et al, 1998).

The adhesion of heterotrophic plate count bacteria on stainless steel coupons was noted during the study period of $96 \mathrm{~h}$ (Table 1). The ANOVA F-test showed a significant difference in heterotrophic plate count bacteria for the control (non-disinfected water), chlorinated and chloraminated water (ratio or $\left.\mathrm{F}_{(2,11)}=22.49, p<0.00013\right)$. The least significance difference (LSD) also indicated a significant difference between heterotrophic plate count bacteria in the non-disinfected water and chlorinated water $(p<0.00285)$, the non-disinfected water and chloraminated water $(p<0.00004)$, and the chlorinated and chloraminated water $(p<0.01542)$. Results of this experiment revealed the effectless of monochloramine in controlling the growth of attached heterotrophic plate count bacteria in laboratoryscale unit within $96 \mathrm{~h}$ after disinfection.

While the attachment of $E$. coli in early biofilm formation was obvious in the non-disinfected water and chlorinated water distribution systems, no $E$. coli were detected on the stainless steel coupons exposed to the monochloramine treated water for the whole of the study period. The ANOVA F-test showed significant difference in $E$. coli counts for different water treatments $\left(\mathrm{F}_{2,17}=7.10, p<0.00577\right)$. The LSD test also indicated a significant difference in $E$. coli counts between non-disinfected water and chloraminated water $p<0.00320)$, and chlorinated and chloraminated water $(p<0.00706)$. However, the test indicated no significant difference in $E$. coli counts for the non-disinfected water and chlorinated water. These results showed the effectiveness of monochloramine in preventing the attachment of $E$. coli during early biofilm formation as well as the resistance of $E$. coli to chlorination 
and their attachment in young biofilms. This observation supported the findings of others showing the capability of coliform bacteria to survive high disinfectant doses of chlorine (Tracy et al., 1966; LeChevallier et al., 1988b). Previous investigators have shown that many coliforms survive standard chlorine residuals as chlorine-injured cells, with subsequent release in distribution systems (McFeters et al., 1986).

By the above analyses, there was abundant statistical evidence that monochloramine was effective not only in preventing the growth or attachment of E. coli during biofilm formation, but also in controlling the growth of attached heterotrophic bacteria.

Acknowledgements-The authors wish to thank Environmentek, Council for Scientific and Industrial Research (C.S.I.R.), Pretoria/South Africa, who sponsored this investigation and Mr. R. A. Agbadzi, Department of Statistics, University of Fort Hare, for his help in the statistic lay-out.

\section{REFERENCES}

APHA (1989) Standard Methods for the Examination of Water and Wastewater, 17th edn. American Public Health Association, Washington, DC.

Burke V., Robinson J., Gracey M., Peterson D. and Partridge K. (1984) Isolation of Aeromonas hydrophila, from a metropolitan water supply: seasonal correlation with clinical isolates. Appl. Environ. Microbiol. 48, 361-366.

Craun G. F. (1985) Waterborne Disease in the United States. CRC Press, Boca Raton, FL, p. 295.

Craun G. F. (1991) Causes of waterborne outbreaks in the U.S. Water Sci. Technol. 24, 17-20.

Craun G. F., Bull R. J., Clark R. M., Doull J., Grabow W., Marsh G. M., Okun D. A., Regli S., Sobsey M. D. and Symons J. M. (1994a) Balancing chemical and microbial risks of drinking water disinfection. Part I. Benefits and potential risks. Aqua 43b, 192-199.

Engel H. W. B., Berwald L. G. and Havelaar A. H. (1980) The occurrence of Mycobacterium kansasii in tap water. Tubercle 61, 21-26.

Geldreich E. E. and Rice E. W. (1987) Occurrence, significance and detection of Klebsiella in water systems. /. AWWA 79,74-80.

Grabow W. O. K. (1996) Waterborne diseases: update on water quality assessment and control. Water SA 22(2), 193-201.

LeChevallier M. W. and McFeters G. A. (1985) Interactions between heterotrophic plate count bacteria and coliforms organisms. Appl. Environ. Microbiol. 49, 1338-1341.

LeChevallier M. W., Babcock T. M. and Lee R. G. (1987) Examination and characterization of distribution system biofilms. Appl. Environ. Microbiol. 53(12), 2714-2724.

LeChevallier M. W., Cawthon C. D. and Lee R. G. (1988b) Mechanisms of bacterial survival in chlorinated drinking water. Water Sci. Technol. 20(11-12), 145-151.

Lippy E. C. and Waltrip S. C. (1984) Waterborne disease outbreaks 1946-1980: a thirty-five-year perspective. J. AWWA 16, 6067.

Mathieu L., Paquin J. L., Hartemann P. and Colin F. (1992) Parametres controlant Vaccumulation de bacteries dans les reseaux de distribution: approche experimantale. Seminaire International. Matiere organique biodegradable dans les reseaux de distribution. Nancy.

McFeters G. A., Kippin J. J. and LeChevallier M. W. (1986) Injured coliforms in drinking water. Appl. Environ. Microbiol. 51, 1 5.

Momba M. N. B., Cloete T. E., Venter S. N. and Kfir R. (1998) Evaluation of the impact of disinfection processes on the formation of biofilms in potable surface water distribution systems. Water Sci. Technol., in press.

Reasoner D. J. and Geldreich E. E. (1985) New medium for the enumeration and subculture of bacteria from potable water. Appl. Environ. Microbiol. 49, 1-7.

Ridgway H. F. and Olson B. H. (1982) Chlorine resistance pattern of bacteria from drinking water systems. Appl. Environ. Microbiol. 44, 972-987.

Tracy H. W., Camarena V. M. and Wing F. (1966) Coliform persistence in highly chlorinated water. /. AWWA 58, 1151-1159.

van der Wende E. and Characklis W. G. (1990) Biofilms in potable water distribution systems. In Drinking Water Microbiology: Progress and Recent Developments, ed. G. A. McFeters, pp. 249-268. Springer-Verlag, New York.

Wierenga J. T. (1985) Recovery of coliforms in the presence of the free chlorine residual. /. AWWA 42(9), 849.

White D. C, Arrage A. A., Nivens D. E., Palmer R. J., Rice J. F. and Sayler G. S. (1996) On-line methods bring new insights into MIC and microbial biofouling. Biofouling 10(1-3), 3-16.

WHO (1996) Guidelines for Drinking-Water Quality, 2nd edn, Vol. 2. Health criteria and other supporting information. World Health Organization, Geneva, 973 pp.

Wadowsky R. M., Yee R. B., Mezmar L., Wing E. J. and Dowling N. J. (1982) Hot water systems as sources of Legionella pneumophila in hospital and non-hospital plumbing fixtures. Appl. Environ. Microbiol. 43, 1104-1110. 